\title{
INFORMATIVE ADVERTISING AND CONSUMER SEARCH IN A DIFFERENTIATED-PRODUCTS DUOPOLY
}

\section{Levent Çelik}
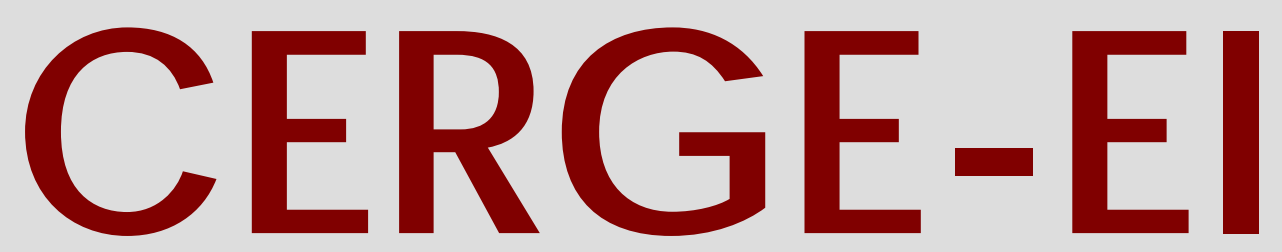

Charles University CenterforEconomic Research and Graduate Education Academy of Sciences of the Czech Republic Ec onomic s Institute 


\section{Working Paper Series 332 (ISSN 1211-3298)}

\section{Informative Advertising and Consumer Search in a Differentiated-Products Duopoly}

Levent Çelik

CERGE-EI

Prague, July 2007 
ISBN 978-80-7343-131-0 (Univerzita Karlova. Centrum pro ekonomický výzkum a doktorské studium)

ISBN 978-80-7344-120-3 (Národohospodářský ústav AV ČR, v.v.i.) 


\title{
Informative Advertising and Consumer Search in a Differentiated-Products Duopoly ${ }^{*}$
}

\author{
Levent Çelik
}

CERGE-EI ${ }^{\dagger}$

May 2007

\begin{abstract}
This paper analyzes informative advertising in a duopoly market with differentiated products when consumer search is costless. If consumers are fully rational, exposure to a single advertisement is sufficient for them to obtain complete market information. In this case, firms undersupply advertising compared to the social optimum because of free-riding. If consumers are not fully rational, they may ignore the existence of another firm when the only advertisement they receive quotes the monopoly price. In this case, both firms advertise the monopoly price, and the market may produce too much or too little advertising compared to the social optimum.
\end{abstract}

\begin{abstract}
Abstrakt
Tato studie analyzuje informativní reklamu na trhu, kde působí duopol s diferencovanými výrobky, za podmínek, kdy spotřebitelé mohou bez nákladů na trhu hledat. Když jsou spotřebitelé plně racionální, stačí, aby byli vystaveni působení jediné reklamy, a získají tím kompletní informace o celém trhu. Firmy potom kvůli reklamám konkurentů poskytují méně reklamy, než by bylo sociálně optimální. Když nejsou spotřebitelé plně racionální, můžou ignorovat existenci druhé firmy, pokud jediná reklama, kterou obdrží, obsahuje monopolní cenu. V tomto případě obě firmy posílají reklamy, ve kterých nabízejí zboží za monopolní cenu a tržní rovnováha tedy může poskytovat př́iliš mnoho nebo př́liš málo reklamy v porovnání se sociálním optimem.
\end{abstract}

Keywords: Search, Duopoly, Informative Advertising, Product Differentiation. JEL Classification: L13, M37

*I am grateful to Simon Anderson and Maxim Engers for their invaluable help during the progress of this paper. Thanks also go to Avner Shaked, Krešimir Žigić and Richard Stock for helpful suggestions. I am responsible for all errors.

${ }^{\dagger}$ CERGE-EI is a joint workplace of the Center for Economic Research and Graduate Education, Charles University, and the Economics Institute of the Academy of Sciences of the Czech Republic.

Address: CERGE-EI, P.O. Box 882, Politických vězňů 7, 111 21, Praha 1, Czech Republic.

Email: Levent.Celik@,cerge-ei.cz. 


\section{Introduction}

In their seminal paper, Grossman and Shapiro (1984) (henceforth, GS) find that informative advertising is overprovided relative to the social optimum when products are differentiated and the number of firms is sufficiently large. This finding rests on a crucial assumption: consumers are passive in that they do not engage in search or any other information acquisition activities. They argue that this may be the case when consumers remain unaware about the existence of a product unless they are reached by its advertisement, or when the search costs are sufficiently high. Thus, the only brands consumers are aware of and informed about are the ones whose ads reach them. In this paper, I analyze the implications of introducing consumer search into the GS model.

When consumers are ex-ante unaware of product existence, they naturally do not consider search until they receive an ad. The first ad they receive raises awareness about the existence of a market for the advertised product and it possibly prompts a willingness to gather more information by searching. At this point, however, a technical problem arises: what beliefs are they going to base their optimal search behavior on? They do not know if there are any other firms in the market nor do they know if this is a differentiated good. So, one needs to define a theory for how beliefs evolve to address these issues.

I take a simple approach in this paper and assume that search is costless. The complications described in the previous paragraph do not arise under this assumption. ${ }^{1}$ There is a single good which can be sold in different varieties (i.e. brands) by different firms. Consumers are initially unaware of the existence of such a good, and hence of the market structure. Firms randomly send out their ads in order to inform consumers about the existence, the characteristics and the price of the brand they sell. I consider two alternative scenarios. In the first one, I assume that consumers are fully rational. This implies that exposure to a single ad enables them to obtain complete information about the market since it raises awareness about the existence of the good. In the second scenario, I assume that consumers are "ignorant" in the sense that they ignore the possibility that other firms exist when contacted with only one brand's ad containing a price that only a monopolist would choose. Thus, by advertising the monopoly price, a firm may be able to convince a subset of consumers that there are no other varieties of this good. If

\footnotetext{
${ }^{1} \mathrm{~A}$ theory for how beliefs are formed is not required when search is costless.
} 
the ad contains a price that a monopolist would not choose, on the other hand, these ignorant consumers infer that there exists at least one more brand offered by a different firm. Therefore, they conduct a search and find out all the relevant market information.

I next characterize the price-advertising equilibria under both alternative specifications and investigate how the market level of advertising compares to the socially optimal amount. For simplicity, I assume that there are only two brands in the market offered by two firms. When consumers are rational, firms charge a lower price in a symmetric equilibrium compared to its level in GS, and advertising is always undersupplied relative to the socially optimal amount. This is mainly because of an apparent free-riding problem: if my rival is going to choose a price different from the monopoly one, then I do not need to advertise to those consumers who my rival advertises to. So, advertising serves as a public good. When consumers are ignorant, on the other hand, advertising is no longer a pure public good. I find that there exists a symmetric Nash equilibrium in which firms set their prices at the monopoly level and possibly undersupply advertising relative to the social optimum. Ignorant consumers do not conduct a search in this equilibrium. Lucky ones receive both ads while unlucky ones receive only one firm's ads and think that the market is monopoly. These findings are in sharp contrast with those of GS.

There is a vast literature on informative advertising. One of the central questions addressed in this literature is whether the market produces too much or too little advertising compared to the socially optimal amount. The market outcome may differ from the socially optimal allocation because of three distinct effects advertising creates. First, advertising can increase the total market size by drawing in new consumers. Second, informative advertising improves the match between consumers and brands. In both cases, the additional surplus is typically divided between sellers and buyers. However, firms do not consider the benefits accruing to consumers when choosing their advertising levels. Therefore, advertising tends to be undersupplied in the market equilibrium. And third, firms advertise in order to increase their own profits. Therefore, they do not take into account the reduction in the profits of the rival firms because of their ads. This causes advertising to be oversupplied in the market equilibrium.

When products are homogeneous, Butters (1977) finds that the market produces the socially optimal amount of advertising. Stegeman (1991) extends Butters' analysis to include heterogeneous valuations and finds that advertising is undersupplied. Similarly, Stahl (1994) 
finds that it is undersupplied when consumers have downward sloping demands. When products are differentiated, GS find that firms oversupply informative advertising irrespective of the degree of differentiation. Contrary to this result, two recent papers, Christou and Vettas (2003) and Hamilton (2004), find that it actually depends on the degree of product differentiation. Christou and Vettas (2003) analyze informative advertising in a random-utility model of product differentiation with possible non-localized competition. ${ }^{2}$ Hamilton (2004) extends GS by allowing for incomplete coverage and considering quantity competition as well. ${ }^{3}$ Both papers find that advertising is oversupplied only when products are sufficiently differentiated. ${ }^{4}$

\section{The Model}

The market consists of two firms who sell different varieties (i.e. brands) of the same good to a group of consumers. The product space is described by a circle of unit circumference around which firms are located $\frac{1}{2}$ unit away from each other. I assume, for simplicity, that production is costless. Consumers are initially unaware of the existence of the good, and hence of the firms. They stay unaware about this existence until they are reached by advertising. The role of advertising is to convey information about a firm's product to consumers. Following Butters (1977), firms send independent ads and have no ability to target ads towards particular consumers.

Ads are truthful and contain information about the price and the true location of the individual variety. Exposure to an ad makes a consumer learn about the existence of such a good and realize her ideal variety. Each consumer is identified by a point on the circle that corresponds to her ideal variety. I assume that consumers are distributed uniformly around the circle with a density of 1 . Each consumer purchases at most one unit and receives a gross value of $v$ from consuming her ideal variety. A consumer whose ideal variety differs from a firm's variety by a distance of $d$ units obtains a net benefit of $v-t d-p$, where $p$ is the price the consumer pays to purchase the product and $t$ is a parameter that measures the disutility associated with

\footnotetext{
${ }^{2} \mathrm{GS}$ focus on local deviations around a symmetric equilibrium, thus ignoring the possibility that a global deviation to a high price is not profitable.

${ }^{3} \mathrm{GS}$ consider only the case of full market coverage in which all partially and fully informed consumers make a purchase.

${ }^{4}$ Hamilton (2004) also finds that advertising is always undersupplied when the two products are homogeneous.
} 
a mismatch between a consumer's ideal variety and the consumed variety. When $t$ is small (large), consumers perceive the two varieties as good (bad) substitutes. So, $t$ is a measure of differentiation from consumers' perception. Consumers rely on the information received from ads to locate specific brands in the product space.

Consumer search is costless. Since consumers are initially assumed to be completely unaware of the existence of the good, they do not engage in search in the absence of an ad. In subsection 2.1, I consider the case of rational consumers in which any consumer who receives at least one ad conducts a search, and hence obtains full information about the market. In subsection 2.2, I consider the case of ignorant consumers in which a consumer does not engage in a search if she is reached by only one firm's ad and the advertised price is that a monopolist would choose. So, she remains unaware of the existence of the other firm when the only advertised price is at the monopoly level. A different price, on the other hand, prompts a consumer to speculate on the existence of other firms. Since search is costless, she conducts a search and finds out the location and price information of the other firm. Consumers only purchase the good if they are aware of a brand that offers a positive net surplus, and a consumer who is aware of both brands selects the one that offers the highest net surplus.

Let $\phi_{i}$ denote the advertising intensity of firm $i$, which measures the reach of the advertising campaign. So, $\phi_{i}$ is interpreted as the fraction of consumers exposed to the ad of firm $i$ at least once. This divides consumers into four types. With probability $\phi_{i} \phi_{j}$, a consumer simultaneously receives ads from both firm $i$ and firm $j(j \neq i)$; with probability $\phi_{i}\left(1-\phi_{j}\right)$, a consumer only receives an ad from firm $i$; with probability $\left(1-\phi_{i}\right) \phi_{j}$, a consumer only receives an ad from firm $j$; and with probability $\left(1-\phi_{i}\right)\left(1-\phi_{j}\right)$, a consumer does not receive any ads from either firm. I assume that the cost of achieving a reach of $\phi$ by an advertising campaign takes a simple form. It is given by $A(\phi)=a \phi^{2}$, where $a$ is a positive constant.

It is constructive to find the monopoly equilibrium first (i.e. when there is one firm in the market). An informed consumer finds it worthwhile to purchase the advertised brand if consuming it yields a nonnegative consumer surplus. This requires that $p \leq v-t d$ for a consumer who is located $d$ units away from the location of the brand. Note that $d=\frac{1}{2}$ is the highest possible distance from an advertised brand. When $v<t$, the monopolist would not find it optimal to set a price that is low enough so as to make each recipient of an ad purchase 
the good. Given that the monopolist chooses an ad reach of $\phi$, its total demand is given by

$$
D=\left\{\begin{array}{ll}
\phi\left[2 \frac{v-p}{t}\right] & , \text { if } p>v-\frac{t}{2} \\
\phi & , \text { if } p \leq v-\frac{t}{2}
\end{array} .\right.
$$

The price that maximizes $\pi=\phi\left(\frac{2(v-p)}{t}\right) p-A(\phi)$ is easily found to be $\frac{v}{2}$. Note that the profit function is concave in price when $p>v-\frac{t}{2}$, so the second-order condition is satisfied. For all informed consumers to be served in the monopoly equilibrium, we need that $v \geq t$. When $v \geq t$, the monopolist can increase its price to $v-\frac{t}{2}$ without losing any (informed) consumers. Given that $p=v-\frac{t}{2}$, the profits of the monopolist can be expressed as

$$
\pi=\phi\left(v-\frac{t}{2}\right)-a \phi^{2}
$$

The profit-maximizing advertising intensity is then $\frac{1}{2 a}\left(v-\frac{t}{2}\right)$.

I examine only the case in which the monopoly price is sufficiently low so that an informed consumer located at the most distant location from the advertised brand finds it worthwhile to purchase it. In this sense, the market is completely covered.

\section{Assumption $1 v>t$.}

Strict inequality also ensures that consumers can distinguish the monopoly price. This will be necessary for the analysis in subsection 2.2. I also assume that it is too costly for a monopolist to reach everyone by advertising.

Assumption $2 v-\frac{t}{2}<2 a$.

This assumption also ensures that the optimal advertising intensities in the following subsections are less than 1.

\subsection{Rational Consumers}

When consumers are fully rational, a direct implication of costless search is that all partially informed consumers conduct a search. As a result, all consumers reached by at least one ad obtain full information regarding the market. Regardless of the exact locations of the two brands, the 
total demand that accrues to firm $i$ in this case is $\left(1-\left(1-\phi_{i}\right)\left(1-\phi_{j}\right)\right)\left(\frac{1}{2}+\frac{p_{j}-p_{i}}{t}\right)$, where $\left(1-\phi_{i}\right)\left(1-\phi_{j}\right)$ is the fraction of consumers who are not reached by the ads of either firm. Each firm maximizes its profits with respect to price and the advertising intensity. The profit function of firm $i$ is

$$
\pi_{i}=\left(1-\left(1-\phi_{i}\right)\left(1-\phi_{j}\right)\right)\left(\frac{1}{2}+\frac{p_{j}-p_{i}}{t}\right) p_{i}-a \phi_{i}^{2}
$$

The first-order conditions with respect to $p_{i}$ and $\phi_{i}$ are

$$
\begin{gathered}
\frac{\partial \pi_{i}}{\partial p_{i}}=\left(1-\left(1-\phi_{i}\right)\left(1-\phi_{j}\right)\right)\left(\frac{1}{2}+\frac{p_{j}-2 p_{i}}{t}\right)=0 \\
\frac{\partial \pi_{i}}{\partial \phi_{i}}=\left(1-\phi_{j}\right)\left(\frac{1}{2}+\frac{p_{j}-p_{i}}{t}\right) p_{i}-2 a \phi_{i}=0 .
\end{gathered}
$$

The second-order conditions are easily seen to be satisfied. At a symmetric Nash equilibrium, both firms choose the same price and the same advertising intensity. Let these be denoted by $p^{R}$ and $\phi^{R}$, respectively, where the superscript $R$ refers to rational. Inserting the symmetry condition into the first-order conditions, we get

$$
\begin{gathered}
\left(1-\left(1-\phi^{R}\right)^{2}\right)\left(\frac{1}{2}-\frac{p^{R}}{t}\right)=0 \\
\left(1-\phi^{R}\right) \frac{p^{R}}{2}-2 a \phi^{R}=0 .
\end{gathered}
$$

Equation (1) implies that $\phi^{R}>0$, so $\left(1-\left(1-\phi^{R}\right)^{2}\right) \neq 0$. Hence, the equilibrium price from equation (1) is

$$
p^{R}=\frac{t}{2}
$$

Inserting this into equation (2), we get

$$
\phi^{R}=\frac{t}{8 a+t} .
$$

The profits of each firm are $\pi^{R}=\left(1-\left(1-\phi^{R}\right)^{2}\right) \frac{p^{R}}{2}-a\left(\phi^{R}\right)^{2}$. After rearranging, we 
get

$$
\pi^{R}=\left(3 a+\frac{p^{R}}{2}\right)\left(\phi^{R}\right)^{2} .
$$

\subsection{Ignorant Consumers}

In this subsection, I find the symmetric duopoly equilibrium when partially informed consumers do not engage in a search if the advertised price is at the monopoly level. A firm has two options in this specification. The first option is to choose the monopoly price, in which case the consumers who receive only that firm's ads would think there are no other firms, and thus would purchase the brand offered by that firm. The second option is to choose a different price, in which case the ad recipients would understand that there is at least one more firm offering the same good, possibly in a different variety.

Suppose firm 2 sets $p_{2}=v-\frac{t}{2}$, which is the price level that a monopolist would choose. Let this price be denoted by $p^{M}$. If firm 1 also chooses to set its price equal to $p^{M}$, two firms equally split the consumers who receive both firms' ads. A fraction $\phi_{1}\left(1-\phi_{2}\right)$ of consumers only receive firm 1's ads, so they purchase the brand offered by firm 1 . If firm 1 chooses a different price, the recipients of its ads infer that firm 1 is not the only firm. Therefore, they conduct a search and find out that there is another brand offering the same good at a price of $p^{M}$. Regardless of the exact locations of the two brands, the demand that accrues to firm 1 from these fully informed consumers is $\phi_{1}\left(\frac{1}{2}+\frac{p_{2}-p_{1}}{t}\right)$ as long as they are located $\frac{1}{2}$ unit apart from each other.

In a symmetric non-cooperative Nash equilibrium in which both firms act as if they offer the only brand of the good, both firms set the price at the monopoly level and then maximize the resulting profits with respect to the intensity of advertising. With a little abuse of notation, I will denote the equilibrium advertising reach and the resulting profits in this situation with the superscript $M$. Suppose it is given that $p_{2}=p^{M}$. If firm 1 chooses $p_{1}=p^{M}$ as well, its profits are

$$
\pi_{1}=p^{M}\left[\phi_{1}\left(1-\phi_{2}\right)+\frac{\phi_{1} \phi_{2}}{2}\right]-a \phi_{1}^{2}
$$

The first-order condition with respect to $\phi_{1}$ is

$$
\frac{\partial \pi_{1}}{\partial \phi_{1}}=p^{M}\left(1-\frac{\phi_{2}}{2}\right)-2 a \phi_{1}=0 .
$$


At a symmetric equilibrium $\phi_{1}=\phi_{2}$. Letting $\phi^{M}$ denote this common value of advertising intensity, we get

$$
\phi^{M}=\frac{p^{M}}{2 a+\frac{1}{2} p^{M}} .
$$

The resulting profits of each firm in this equilibrium can be found as

$$
\pi^{M}=\frac{a\left(p^{M}\right)^{2}}{\left(2 a+\frac{1}{2} p^{M}\right)^{2}}=a\left(\phi^{M}\right)^{2} .
$$

Firm 1 would choose a different price if it is able to achieve higher profits. Given that $p_{2}=p^{M}$ and $\phi_{2}=\phi^{M}$, if firm 1 chooses a price $p_{1} \neq p^{M}$, its profits are

$$
\pi_{1}=p_{1}\left[\phi_{1}\left(\frac{1}{2}+\frac{p^{M}-p_{1}}{t}\right)\right]-a \phi_{1}^{2} .
$$

Evaluated at $p^{M}=v-\frac{t}{2}$, the first term above becomes $p_{1} \phi_{1}\left(\frac{v-p_{1}}{t}\right)$. The first-order conditions with respect to $p_{1}$ and $\phi_{1}$ are

$$
\begin{gathered}
\frac{\partial \pi_{1}}{\partial p_{1}}=\phi_{1}\left(\frac{v-2 p_{1}}{t}\right)=0 \\
\frac{\partial \pi_{1}}{\partial \phi_{1}}=p_{1}\left(\frac{v-p_{1}}{t}\right)-2 a \phi_{1}=0 .
\end{gathered}
$$

Note that $\pi_{1}$ is strictly concave in $p_{1}$ and $\phi_{1}$, so the first-order conditions give the profitmaximizing price and advertising intensity. Let these be denoted by $p^{D}$ and $\phi^{D}$, and the resulting profits denoted by $\pi^{D}$. Solving equation (7) for $p_{1}$ and assuming that $t<v \leq 2 t$, we get

$$
p^{D}=\frac{v}{2}
$$

Substituting this into equation (8) and solving for $\phi_{1}$ gives

$$
\phi^{D}=\frac{v^{2} / 4 t}{2 a} .
$$

So, the profits of firm 1 in this non-symmetric situation are

$$
\pi^{D}=\frac{v^{4}}{64 a t^{2}}=a\left(\phi^{D}\right)^{2} .
$$


Firm 1 would choose this strategy if $\pi^{D}>\pi^{M}$, which is true when $\phi^{D}>\phi^{M}$. However, this is impossible to occur when $t<v<2 t$.

Proposition 1 Both firms choose the monopoly price and the corresponding advertising intensity in a symmetric Nash equilibrium provided that the following three conditions are satisfied: (i) The market is completely covered in equilibrium when there is a single firm, i.e. $v>t$; (ii) A monopolist would find it too costly to send advertising messages to everyone, i.e. $v-\frac{t}{2}<2 a$; (iii) When the market is served by two firms, neither firm is able to sell to all of its ad recipients by undercutting its rival, i.e. $v<2 t$.

Proof. Let $\frac{v}{t}=x, \frac{a}{t}=y$. Then, $\phi^{D}$ and $\phi^{M}$ can be expressed as

$$
\phi^{D}=\frac{(x / 2)^{2}}{2 y}, \quad \phi^{M}=\frac{1}{\frac{4 y}{2 x-1}+\frac{1}{2}} .
$$

$\phi^{M}>\phi^{D}$ if and only if

$$
\frac{1}{(x / 2)^{2}}>\frac{\frac{4 y}{2 x-1}+\frac{1}{2}}{2 y} \Leftrightarrow \frac{4}{x^{2}}-\frac{2}{2 x-1}>\frac{1}{4 y} .
$$

By Assumption 2, we have $4 y>2 x-1$, so $\frac{1}{2 x-1}>\frac{1}{4 y}$. It now suffices to show

$$
\frac{4}{x^{2}}-\frac{2}{2 x-1}>\frac{1}{2 x-1}
$$

which would then imply $\phi^{M}>\phi^{D}$. Rearranging the above inequality, we get

$$
3 x^{2}-4(2 x-1)<0 \text {. }
$$

The left-hand side equals $(3 x-2)(x-2)$, which is negative for all $\frac{2}{3}<x<2$. So, $\phi^{M}>\phi^{D}$ for all $t<v<2 t$ as claimed in the proposition.

When $v>2 t$, each consumer who receives firm 1's advertising message in the nonsymmetric situation purchases firm 1's brand. Therefore, there is more incentive for undercutting the rival if it is charging the monopoly price. Whether this yields higher profits depends on the size of advertising costs. If it is too costly to advertise, then it is optimal to follow suit 
and charge the monopoly price.

Given that the two brands are located $\frac{1}{2}$ unit apart from each other, the consumer for whom firm 2's brand is the ideal one derives a utility of $v-p^{M}=\frac{t}{2}$ from consuming it. If she chooses to consume firm 1's brand, her net utility is $v-\frac{t}{2}-p_{1}$. This is greater than $\frac{t}{2}$ when $p_{1}>v-t$. So, when $v>2 t$, firm 1 optimally sets $p^{D}=v-t$, thus capturing all consumers who receive at least one ad from firm 1. Substituting $p^{D}$ into equation (8) implies $\phi^{D}=\frac{p^{D}}{2 a}=\frac{v-t}{2 a}$, and the resulting profits are $\pi^{D}=\frac{(v-t)^{2}}{4 a}=a\left(\phi^{D}\right)^{2}$. Note that $\phi^{D}=\frac{v-t}{2 a}<1$ by Assumption 2.

Firm 1 earns a higher level of profits by charging a lower price if $\phi^{D}>\phi^{M}$.

$$
\phi^{D}>\phi^{M} \Leftrightarrow \frac{v-t}{2 a}>\frac{1}{\frac{4 a}{2 v-t}+\frac{1}{2}} .
$$

Rearranging the terms above, we get $(v-t)(2 v-t)>4 a t$ for $\phi^{D}>\phi^{M}$.

Proposition 2 When $v>2$, both firms choose the monopoly price and the corresponding advertising intensity in a symmetric Nash equilibrium only if $(v-t)(2 v-t)<4 a t$.

Comparing this result with the one presented in Proposition 1, we see that the level of advertising costs comes into consideration only when consumers' willingness to pay for the good is high enough. This is because a firm does not need to lower its price too much in order to capture from its rival all the consumers it can reach by advertising. However, this leads to a reduced incentive for achieving a high advertising reach, especially when advertising is more costly relative to consumers' willingness to pay. Therefore, when it is too costly to advertise, each firm chooses to charge the monopoly price and achieve a higher advertising reach.

A comparison with the equilibrium advertising intensity found in the previous subsection yields that firms generally advertise less when consumers are rational. The underlying reason is that advertising in that case is treated as a public good. Since a firm's advertising also informs its recipients about the other brand, their incentive for free-riding on their rival's ads increases. Therefore, they advertise less. 


\section{Welfare Analysis}

In this section, I find the socially optimal allocation of advertising for given price levels. Then, I compare the market level of advertising to the level that maximizes social welfare. The welfare standard used is the conventional one of consumer surplus plus profits. Aggregate welfare is given by

$$
W=v\left[1-(1-\phi)^{2}\right]-2 a \phi^{2}-T,
$$

where $T$ represents the aggregate consumer disutility associated with consuming a brand that is not the ideal one. The first term in the welfare function represents consumer benefits gross of disutility associated with consuming a brand that is not the ideal one. The term $1-(1-\phi)^{2}$ is the fraction of consumers who purchase the good. The second term $2 a \phi^{2}$ is the total advertising costs that firms incur.

The calculation of $T$ deserves some caution. Consumers who purchase the good can be partitioned into two groups. The first group comprises those consumers who purchase the brand that is closer to their ideal brands. The average distance between the ideal brand of a random consumer in this group and the brand that is consumed is $1 / 8$. The second group comprises unlucky consumers who end up purchasing the brand that is farther from their ideal brands. The average distance between the ideal brand of a random consumer in this group and the brand that is consumed is $3 / 8$. When consumers are rational, all of them belong to the first group. When they are ignorant, some of them belong to the second group.

\subsection{Rational Consumers}

When consumers are rational, all consumers reached by advertising purchase their most preferred brand. So, the aggregate transportation costs are

$$
T=\frac{1-(1-\phi)^{2}}{8} t
$$

The social welfare function becomes

$$
W=\left(1-(1-\phi)^{2}\right)\left(v-\frac{t}{8}\right)-2 a \phi^{2}
$$


which is maximized at $\phi^{S}=\frac{2 v-\frac{t}{4}}{4 a+2 v-\frac{t}{4}}$. This can be rearranged as

$$
\phi^{S}=\frac{1}{\frac{4 a}{2 v-(t / 4)}+1} .
$$

The market equilibrium, given by equation (4), can be rearranged as $\phi^{R}=\frac{1}{\frac{4 a}{(t / 2)}+1}$. Since $2 v-\frac{t}{4}>\frac{t}{2}$, it follows that $\phi^{R}<\phi^{S}$.

Proposition 3 When consumers are rational, the market always underprovides informative advertising.

The intuition in this case is quite simple. As discussed before, advertising is a public good and therefore free-riding arises.

\subsection{Ignorant Consumers}

Assuming that monopoly pricing is the equilibrium strategy, the probability that an ignorant consumer will purchase the closer brand is simply the advertising intensity chosen by the seller of that brand. Hence, the size of the first group is $\phi$. Similarly, $\phi(1-\phi)$ is the probability that she will purchase the farther brand. So, when consumers are ignorant, the total transportation costs are

$$
T=t\left[\frac{\phi}{8}+\frac{3 \phi(1-\phi)}{8}\right]
$$

Returning to the expression for aggregate welfare, we have

$$
W=v\left[1-(1-\phi)^{2}\right]-2 a \phi^{2}-t\left[\frac{\phi}{8}+\frac{3 \phi(1-\phi)}{8}\right]
$$

The first-order condition with respect to $\phi$ yields

$$
(1-\phi) v-2 a \phi-\frac{(2-3 \phi) t}{8}=0 .
$$

After rearranging, we get

$$
\phi^{S}=\frac{v-\frac{t}{4}}{2 a+v-\frac{3 t}{8}},
$$


where $\phi^{S}$ is the socially optimal advertising intensity of one firm. The second derivative of $W$ is $\left(-v-2 a+\frac{3 t}{8}\right)$, which is negative since $v>t$.

Proposition 4 When consumers are ignorant, the market overprovides informative advertising if $v>\frac{t}{2}+\sqrt{a t}$.

Proof. $\phi^{M}<\phi^{S}$ if and only if

$$
\left(v-\frac{t}{2}\right)\left(2 a+v-\frac{3 t}{8}\right)<\left(v-\frac{t}{4}\right)\left(2 a+\frac{v}{2}-\frac{t}{4}\right)
$$

The right-hand side can be rewritten as $\left(v-\frac{t}{2}\right)\left(2 a+\frac{v}{2}-\frac{t}{4}\right)+\frac{t}{4}\left(2 a+\frac{v}{2}-\frac{t}{4}\right)$. Taking the first of these expressions to the left-hand side, we get

$$
\left(v-\frac{t}{2}\right)\left(\frac{v}{2}-\frac{t}{8}\right)<\frac{t}{4}\left(2 a+\frac{v}{2}-\frac{t}{4}\right)
$$

Reorganizing yields

$$
2\left(\frac{v^{2}}{2}-\frac{v t}{2}+\frac{t^{2}}{8}\right)<a t
$$

$v^{2}-v t+\frac{t^{2}}{4}=\left(v-\frac{t}{2}\right)^{2}$. So, we get $\phi^{M}>\phi^{S}$ if and only if $v-\frac{t}{2}>\sqrt{a t}$.

By Assumption 1, $v>t$. So, by Proposition 4, we get an overprovision of advertising in the market equilibrium if $\frac{t}{2} \geq \sqrt{a t}$. This occurs when $4 a \leq t$. However, this condition violates Assumption 2. So, under these two assumptions, there is no value of the advertising cost parameter $a$ that alone causes firms to overprovide advertising regardless of the degree of differentiation. As the two brands become more similar (i.e. as $t \rightarrow 0$ ), firms always overprovide informative advertising regardless of its cost. Otherwise, it depends on the values of $a$ and $t$. Confining our attention to the case when $t<v \leq 2 t$, if advertising costs are high firms generally underprovide advertising.

The findings in this subsection are in sharp contrast with the existing literature. For a given level of differentiation (i.e. for a given value of $t$ ) a firm has an incentive to advertise more since consumers are ignorant and doing so results in a higher number of consumers who are only informed about that firm's brand. As the two brands get less differentiated, this incentive increases. In such a case, a firm considers the effects of a possible undercutting by its rival (in which case all of the fully informed consumers buy from the rival) and therefore it advertises 
more. However, this effect vanishes as the degree of differentiation or the cost of advertising increases. As consumers start to perceive the two brands as worse substitutes, they will stick with the better one even if it charges the monopoly price. So, a firm can also sell to some of the fully informed consumers and this reduces the incentive for advertising.

\section{Conclusion}

This paper has presented a modified duopoly version of Grossman and Shapiro (1984), the seminal paper on informative advertising. I have added costless consumer search into their analysis. When consumers are ignorant, the findings are strikingly different. Both firms may advertise the monopoly price, and we may get too little advertising compared to the social optimum. This depends on how differentiated consumers perceive the two brands as and how costly advertising is. If the brands are differentiated enough and/or the advertising costs are high enough, the market underprovides advertising. When consumers are fully rational, advertising is always undersupplied. This is because advertising serves as a public good.

The result that monopoly pricing arises may seem to have been driven by the assumption of ignorant consumers. However, I have made this assumption just to get a nontrivial equilibrium in the presence of costless search. In fact, the same pricing strategy should carry over to other, economically more reasonable, specifications. Suppose that search is costly and that consumers are rational. Upon exposure to an ad, they form beliefs about the fixed cost of producing the advertised good. For simplicity, suppose that they postulate three possible values for the fixed cost: a low value which would accommodate only one firm, a moderate value which would accommodate two firms, or a high value which would accommodate three firms. Suppose also that they postulate a uniform distribution for the possible variations of the advertised good. Then, depending on the advertised price(s), consumers make rational inferences, and accordingly decide whether to search or not. In this environment, the monopoly price should arise as an equilibrium outcome when the search cost exceeds a certain minimum threshold value. 


\section{References}

[1] Anderson, Simon P., André de Palma and Jacques-F. Thisse (1992), Discrete Choice Theory of Product Differentiation, MIT Press, Cambridge.

[2] Bagwell, Kyle (2005), "The Economic Analysis of Advertising," mimeo, Columbia University. Forthcoming in Handbook of Industrial Organization Vol. 3, eds. Mark Armstrong and Robert Porter, North-Holland, Amsterdam.

[3] Butters, Gerard R. (1977), "Equilibrium Distributions of Sales and Advertising Prices," Review of Economic Studies, 44:3, pp. 465-491.

[4] Christou, Charalambos and Nicolaos Vettas (2003) "Informative Advertising and Product Differentiation," Center for Economic Policy Research Discussion Paper No. 3953. Forthcoming in International Journal of Industrial Organization.

[5] Dixit, Avinash K. and Victor D. Norman (1978), “Advertising and Welfare,” Bell Journal of Economics, 9:1, pp. 1-17.

[6] Dixit, Avinash K. and Joseph E. Stiglitz (1977), "Monopolistic Competition and Optimum Product Diversity", American Economic Review, 67:3, pp. 297-308.

[7] Grossman, Gene and Carl Shapiro (1984), "Informative Advertising with Differentiated Products," Review of Economic Studies, 51, pp. 63-81.

[8] Hamilton, Stephen F. (2004), “Informative Advertising in Concentrated, Differentiated Markets", mimeo, University of Central Florida.

[9] Meurer, Michael and Dale O. Stahl (1994), "Informative Advertising and Product Match," International Journal of Industrial Organization, 12, pp. 1-19.

[10] Roberts, Jacques and Dale O. Stahl, II (1993), "Informative Price Advertising in a Sequential Search Model," Econometrica, 61:3, pp. 657-686.

[11] Salop, Steven C. (1979) "Monopolistic Competition with Outside Goods", Bell Journal of Economics, 10, pp. 141-156. 
[12] Shapiro, Carl (1980), "Advertising and Welfare: Comment," Bell Journal of Economics, 11, pp. 749-752.

[13] Soberman, David (2002), "Informative Advertising: An Alternate Viewpoint and Implications," Review of Marketing Science Working Papers, 1:3, Working Paper No. 3.

[14] Stahl, Dale O. (1994), “Oligopolistic Pricing and Advertising”, Journal of Economic Theory, 64, pp. 162-177.

[15] Stegeman, Mark (1991), "Advertising in Competitive Markets", American Economic Review, 81, pp. 210-223.

[16] Tirole, Jean (1988), The Theory of Industrial Organization, MIT Press, Cambridge. 
Individual researchers, as well as the on-line and printed versions of the CERGE-EI Working Papers (including their dissemination) were supported from the following institutional grants:

- Economic Aspects of EU and EMU Entry [Ekonomické aspekty vstupu do Evropské unie a Evropské měnové unie], No. AVOZ70850503, (2005-2010);

- Economic Impact of European Integration on the Czech Republic [Ekonomické dopady evropské integrace na ČR], No. MSM0021620846, (2005-2011);

Specific research support and/or other grants the researchers/publications benefited from are acknowledged at the beginning of the Paper.

(c) Levent Çelik, 2007.

All rights reserved. No part of this publication may be reproduced, stored in a retrieval system or transmitted in any form or by any means, electronic, mechanical or photocopying, recording, or otherwise without the prior permission of the publisher.

Published by

Charles University in Prague, Center for Economic Research and Graduate Education (CERGE) and

Economics Institute ASCR, v. v. i. (EI)

CERGE-El, Politických vězňů 7, 11121 Prague 1, tel.: +420 224005 153, Czech Republic.

Printed by CERGE-EI, Prague

Subscription: CERGE-EI homepage: http://www.cerge-ei.cz

Editors: Directors of CERGE and EI

Managing editors: Deputy Directors for Research of CERGE and EI

ISSN 1211-3298

ISBN 978-80-7343-131-0 (Univerzita Karlova. Centrum pro ekonomický výzkum a doktorské studium)

ISBN 978-80-7344-120-3 (Národohospodářský ústav AV ČR, v. v. i.) 
CERGE-EI

P.O.BOX 882

Politických vězňů 7

11121 Praha 1

Czech Republic http://www.cerge-ei.cz 